\title{
Livelihood Srategies and the Welfare of Transmigrants
}

\author{
Yanmesli, R. Rijanta, Nasruddin Harahap
}

Received: 0110 2013/ Accepted: 2010 2013 / Published online: 30062014

(c) 2014 Faculty of Geography UGM and The Indonesian Geographers Association

\begin{abstract}
Transmigration is one of the manifestations of artificial human community that is expected to increase the natural resource utilization activities for welfare in a transmigration location. This paper is to find out the livelihood strategies and their effect on transmigrants' welfare. Results of the study indicates at Stage I (the first 1.5 years), transmigrants generally applied a survival strategy by relying on the living allotment of government. At Stage II (the second 1.5 years), a part of them sougth other source of income for establishing their livelihood. At Stage III (the third 2 years and afterward), a part of them left the transmigration location, while others have able to survive until the primary commodity of rubber can be productive after the sixth year of cultivation. Welfare is achieved by those that could to apply the livelihood strategies to have the established sources of income outside the transmigrants' primary commodity, particularly from Pasuruan, East Java Province.
\end{abstract}

Keywords: Transmigration, artificial human community, livelihood strategies, welfare

\begin{abstract}
Abstrak Transmigrasi merupakan salah satu wujud komunitas manusia buatan yang diharapkan dapat meningkatkan aktivitas pemanfaatan sumberdaya alam pertanian demi kesejahteraan di lokasi transmigrasi. Tulisan ini membahas strategi penghidupan dalam pengelolaan lahan dilihat dari pendekatan ekologi, serta dampaknya terhadap kesejahteraan transmigran. Hasil penelitian ini menunjukkan bahwa pada Tahap I (1,5 tahun pertama), transmigran umumnya menerapkan strategi bertahan dengan hanya mengandalkan jatah hidup dari pemerintah. Pada Tahap II (1,5 tahun kedua), sebagian transmigran mencari sumber pendapatan lainnya untuk memantapkan kehidupannya di lokasi transmigrasi. Pada Tahap III (2 tahun ketiga dan seterusnya), sebagian transmigran tidak dapat bertahan dan meninggalkan lokasi transmigrasi, sedangkan sebagian yang lain memiliki sumber pendapatan yang relatif mapan dan dapat menopang kehidupannya sampai tanaman karet sebagai komoditas pertanian utama berproduksi setelah tahun keenam penanaman. Kesejahteraan hanya dicapai transmigran yang mampu mencari dan menerapkan strategi penghidupan untuk memperoleh sumber pendapatan yang mapan di luar komoditas pertanian utama di lokasi transmigrasi, terutama transmigran asal Pasuruan, East Java.
\end{abstract}

Kata kunci: Transmigrasi, komunitas manusia buatan, strategi penghidupan, kesejahteraan

\section{Introduction}

Transmigration is a program implemented by government, particularly Department of Transmigration [Ramadhan et al., 1993] to distribute populations and develop regions. It is designed to increase human activity in the utilization of natural resources for the welfare of population in the transmigration location [Husodo. 2003]. The transmigrants become prosperous or not are affected by the capacity of applying certain livelihood strategies for survival in establishing other source of income outside that from primary commodity cultivated in the transmigration location, as well as establishing the bases of regional development after the primary agricultural commodity cultivated become productive for the welfare of transmigrants [Kinsey, 2002].

Based on the Government Regulation No. 2/1999 on Transmigraton Implementation, transmigration is Yanmesli

Fakultas Keguruan dan Ilmu Pendidikan, Universitas Prof. Dr. Hazairin, S.H.

Email:memes.maizar@gmail.com

R. Rijanta, Sutikno

Faculty of Geography, Unversitas Gadjah Mada

Nasruddin Harahap

Fakultas Dakwah, Universitas Islam Negeri Sunan Kalijaga carried out as an integral part of national development, to distribute inter-regional development by establishing new centres for regional growth or support the acceleration of existing or developing growth centers. Transmigration is carried out to increase the welfare of transmigrants and the surrounding local communities by the creation of work opportunities and the stimulation of new investment expansion and development. If such program can be performed well, a much more holistic and integrated dynamic of population in sociocultural and economic sectors can occur, in turn reducing the tendency to outmigration as stated by Iden and Richter [1971].

Transmigration is indeed an ideal program as an effort of meeting human right over a better living condition, both for individual, family and community of the transmigrant. However, there are many factors affecting the conditions of welfare amids a wild and natural condition in the transmigration area and not each transmigrant can live with the high level of adaptation. The performane of transmigration and the achievement of welfare in the transmigration area are very heavy efforts for the most people including transmigrants themselves [Lee, 1991]. 


\section{The Methods}

The study was conducted by using a case study method to investigate unique specific phenomenon appropriate with the unique situation and condition in the site of study. The case study used was a deep case study in a certain case by focusing attention to the contemporary phenomenon in the real life context [Yin, 2011] on the livelihood strategies and the welfare of transmigrants. TSU Durian Amparan was selected as the site of study because the region is located in the primary priority areas of regional development toward the regional economic growth in the surrounding regions of the Independent Integrated City (Kota Terpadu Mandiri-KTM) Lagita, in Lais Subdistrict, Girimulya Subdistrict, and Ketahun Sub-district. This TSU have met the criteria of study with the placement of transmigrants in the last five years of 2004, 2005, and 2006, respectively) and actually 115 of $200 \mathrm{HH}$ preferred to leave the transmigration location and went home to the region of origin, implying the fundamental problems encountered by the transmigrants related to the relatively low level of welfare.

To achieve the objectives of the study, data required were two types, i.e. primary and secondary data. The former was directly acquired from field, while the latter was indirectly obtained from various literatures and documents The data collection was done using three ways, including: (a) in-depth interview. It is directly done with key informant by asking them the semistructured questions prepared as a general guideline for the colletion of data that are relevant to the topic of study. According to Moleong [2009], informants are insiders in the setting of research, which are involved to give information on situation and condition of research setting. They are useful to help researchers immersing quickly in the local context, particularly for those with less ethnographic skills [Lincoln and Guba, 1985]. In order to find the key informant, snowball effect method is used by finding the first informant, asking him/ her about other informants, and so forth until some key informants in sufficient number are found, (b) participantory observation. It is done to collect qualitative data about general situation and condition on the location of study. This technique is applied by attending meeting among government, transmigrants, and social figures about their perception on the aspects of life affecting the transmigrants' welfare, and (c) documentation, i.e. the tracking of documents on the implementation of transmigration program including a variety of policies and other related regulations and other literatures about the aspects of welfare enjoyed by transmigrant in TSU Durian Amparan.

The primary and secondary data collected were then analysis by using a descriptive qualitative method through three paths of activity simultaneously, i.e. data reduction, data presentation, and inference [Miles dan Huberman, 2009]. First, data reduction is a selection proces to focus attention and the simplification and ab- straction of raw data in field notes. It occured along the paths of research from a preliminary data collection to the writing of results of study. Second, data presentation is an activity to present information/data arranged orderly, so field information/data presented in writing can be easily read and understood in integrated comprehensive form to draw conclusions. Third, the inference was done as an effort to draw conclusions from anything found in data collection, data reduction, and data presentation.

\section{Result and Discussion}

The transmigration program implemented in TSU Durian Amparan were unseparable from the positive effect of development in some transmigration areas currently called as the Independent Integrated City (Kota Terpadu Mandiri-KTM) Lagita. The area is located in subdistricts: Ketahun, Nepal Putih, Giri Mulya, Batik Nau, Padang Jaya, and Lais Subdistricts. In northern, KTM Lagita has the boundary with Nepal Putih Subdistrict, in eastern, it has the boundary with Air Bintunan River, in southern, it has the boundary with Indonesian Ocean, and in western, it has the boundary with Kelangi River. The areas of KTM Lagita are 92,522 $\mathrm{Ha}$ in wide, most of which are located in Ketahun Subdistrict (53.53\%) and the remaining is included in Batik Nau Subdistrict.

The purpose of the development of KTM Lagita is the transmigration areas can be the centers of agriculture and agroindustry based regional growth, as well as the areas of agribusiness development [Pemerintah Kabupaten Bengkulu Utara, 2007]. Thus, it can be said that policy on the placement of transmigrant in TSU UPT Durian Amparan was not established alone, but also issued in the context of regional development of transmigration location that started since past decades and at present developed in order that the areas can also developed as a part of a collective growth center in KTM Lagita in the future.

Transmigrants in TSU Durian Amparan is $200 \mathrm{HH}$, consisting of three placement years, i.e. in 2004, 100 $\mathrm{HH}$ ( $25 \mathrm{HH}$ from Pasuruan, East Java, $25 \mathrm{HH}$ from DKI Jakarta, and $50 \mathrm{HH}$ from local population), in 2005, 50 $\mathrm{HH}$ from local population, and in 2006, $50 \mathrm{HH}$ from Pasuruan, East Java. The number of population when placed was 810 people. From $200 \mathrm{HH}$, at present there are still $85 \mathrm{HH}$, i.e. 72 from $75 \mathrm{HH}$ from Pasuruan, East Java, 2 from $25 \mathrm{HH}$ from DKI Jakarta, and 11 from 100 $\mathrm{HH}$ from local population. Thus, 115 of $200 \mathrm{HH}$ actually left transmigration location and went home to the region of origin.

Transmigration in TSU Durian Amparan is implemented due to the poor conditions of transmigrants in their regions of origin. It indicates that the transmigration is not the program performed independently in terms of responding lags in resource distribution through mobility toward economic growth centers as stated by 

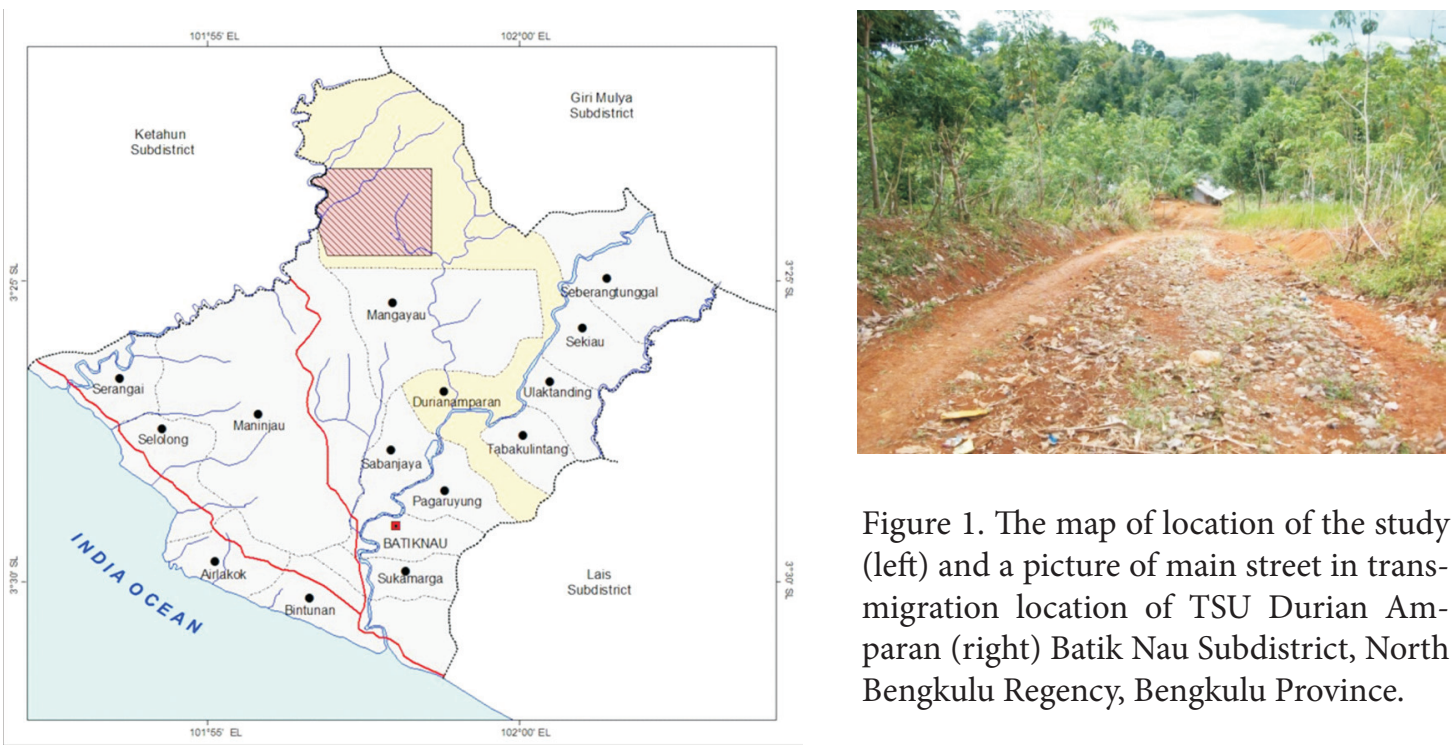

Figure 1. The map of location of the study (left) and a picture of main street in transmigration location of TSU Durian Amparan (right) Batik Nau Subdistrict, North Bengkulu Regency, Bengkulu Province.

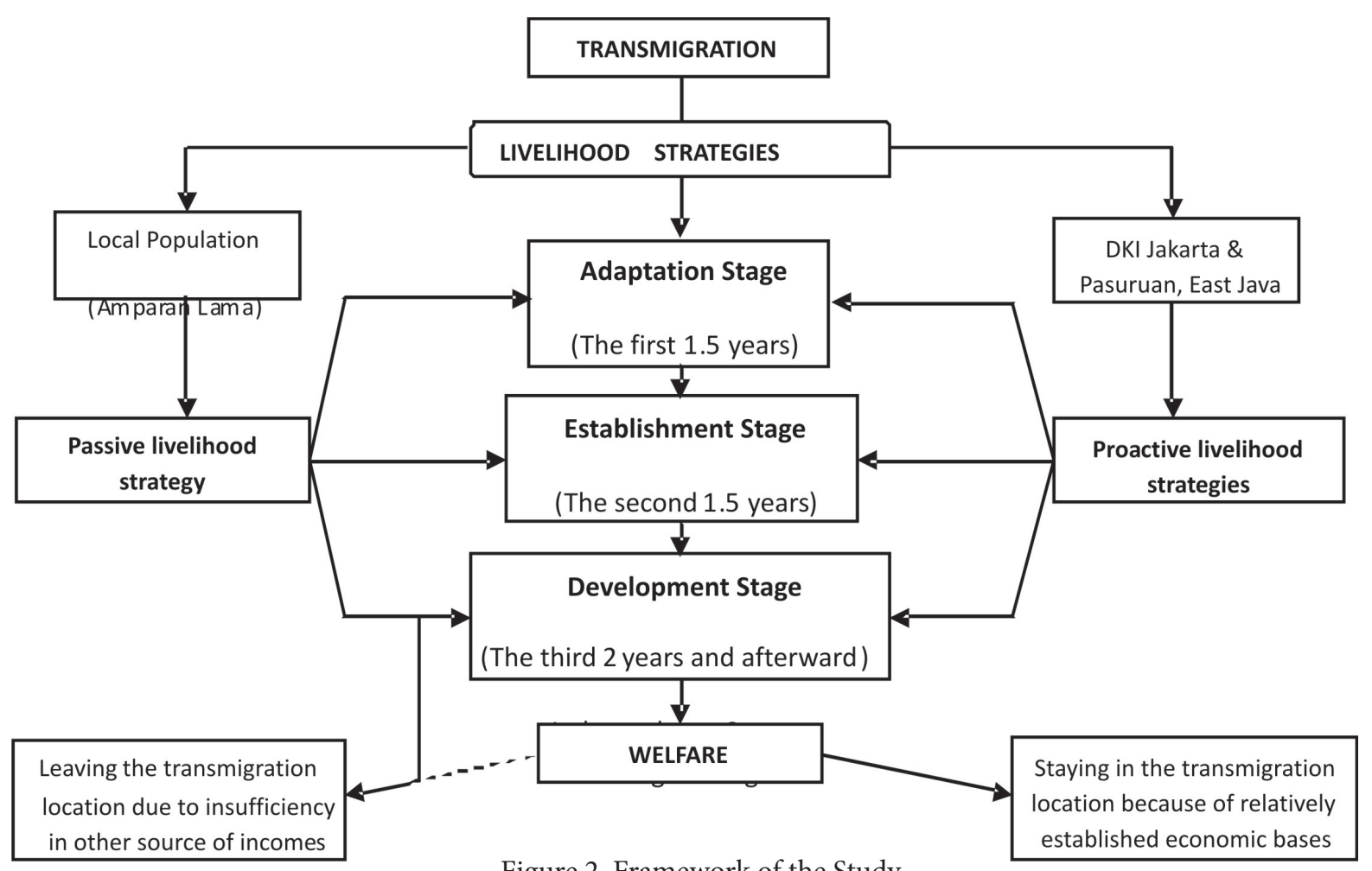

Figure 2. Framework of the Study

Rotge et al. in Rijanta [2003], but because of their poor conditions resulted from structural pressures suffered by transmigrants in their regions of origin.

Generally, transmigrants have understood since the registration to be the participant of transmigration program that living as a transmigrant farmer is not easy. It could be imagined that their first work is to clear the former forest land that must be previously processed, maintain heavy trees for years before production, and seek other source of income that is relatively sufficient during a waiting period for harvest. There are many transmigrants with a good preparation for the condition, and many are actually not able to adapt with the challenges of severe physical environment field.
Each transmigrant has different livelihood strategies in handling the problems they encountered when they were placed in the transmigration location and process some agricultural land given by government. The livelihood strategies applied are different with each other, in the adaptation step (the first 1.5 years), the establishment step (the second 1.5 years), and the development step (the third 2 years and afterward). This difference is influenced by the less access over the adoption of technology as one of the revolusionary strengths in developing society and encourage population to be economically more productive in the frame of development [Beaudry and Green, 2002]. The success in the application of livelihood strategies at each step affects 
their capacity in building economic bases to stand on in managing their lands at the next steps in a sustainable manner.

One of the processes that should be carried out by government at the placement phase is to provide lands for both residency and cultivation with a legal status of ownership [Soegiharto, 2008]. When the placement of transmigrant in TSU Durian Amparan was done, the government only given lands for house and yard of 0.25 hectare in width to be managed by them. Actually, it is also necessary to give the Cultivation Land I at the placement, and given the Cultivation Land II after a year of the placement, so the transmigrants could manage the lands early. However, until a year of placement, the Cultivation Land I was not given yet and just given at the second year, even to date (the eighth year of placement) $15 \mathrm{HH}$ have not been given the Cultivation Land I. By such condition, the transmigrants can only manage the lands for house and yard, not for short-term economic livelihood, but more for the comfort of residence in the new transmigration location. This indicates that local governments, both at provincial and regency levels, have relatively failed to perform their strategic roles as facilitator in succeeding the transmigration program [Suparno, 2007].

During the first year of placement, almost all transmigrants living their everyday life only by relying on the living allotment of government. The subsidy given in the first year of placement were rice, sugar, coffee, salt, salty fish, and so on monthly. By such subsidy in a less reasonable number, it can be assessed that the life of transmigrants has been very simple, and can be said to be under the line of poverty. For those with no other skills except gardening, they have no other choice except to maintain the land for house and yard with only 0.25 hectare in wide without any significant short-term production. Time taken was also not much, only some hours at morning, and after that they generally spent time only for relaxing or gathering among transmigrants. Those from local population tended to apply such unproductive land management model.

For those reluctant to waste time, they are generally to be the rubber tapping labors for the transmigrants from the surrounding transmigration location. Considering that most of transmigrants around KTM Lagita cultivated rubber plant, they have generally worked to be the rubber tapping labors or maintained the rubber land delegated by the owners to be managed with a sharing profit system. Those with wider thinking have relatively been able to save money to the management of land for house and yard better than those with no other productive activity outside the primary agriculture in the transmigration location. At least, they have more been able to renovate house to be better for the more comfort of familial life. By the limited capacity of managing agricultural lands, transmigrants from DKI Jakarta have generally applied a livelihood strategy for survival at the adaptation step.
Transmigrants from Pasuruan, East Java, have applied different and more advanced livelihood strategies. Since the registration as participants of transmigration program, they have generally prepared to handle any challenges of severe physical environmant field to survive and developing better life over times. Also, they have generally had better cultivating or gardening skills, some handicraft skills that are relatively required so much in the transmigration location, and adequate small-scale trading skills. By the supporting skills, as arrived in the location, they have generally been able to adapt with relatively severe physical environment in a better manner. In land management around both house and yard, they have applied the cultivating and gardening system like in East Java, where the lands are processed by applying a teraccering system and those around are planted by fruits and vegetables for shorttime need. By handycraft skills, they can work as carpenter and mason that are required in other relatively developed transmigration locations. Using sufficient capital prepared since the departure, they have been able to buy vehicles for comfort transportation as the facility of connecting transmigration location to other relatively developed regions. The livelihood strategy made the transmigrants more prepared in handling the challenges of severe physical environment and more optimistic that in a certain period of time they will become the prosperous transmigrants with sustainable regional development.

The application of the livelihood strategies at the first year of placement determined how the preparedness of transmigrants in facing the challenges of the second year of placement, particularly when the living allotment of government at the first year of placement ceased to give. The outcomes of livelihood strategy applied in agricultural sector over the very limited land for house and yard alone are different with those of livelihood strategies applied in the rubber tapping labor sector or the maintenance of lands for rubber plants in other relatively developed transmigration locations and the livelihood strategy in handycraft or small-scale trading sectors. The outcome of the adaptation through the selection of more appropriate livelihood strategy at the Stage I can be seen from the preparedness of the transmigrants in entering the next periode of Stage II (establishment phase).

For those with no productive activity, they generally felt to be not prepared in facing the next transmigration process. They have generally relied so much on the allotment given by government with the high level of dependency and become worried when the subsidy ceased [O'Connor, 2004]. In their mind, if the Cultivation Land I was given at the beginning of the second year of the placement, they just cultivate the lands by planting rubber and maintain them until a certain age, being then left after they were sold at a certain price to others in the same transmigration location or other locations. Such practice did not support the success 
of transmigration program and violate the main rules determined i.e. willing to reside and manage the lands given by government and not sell them to others. They tended to do it because they were not able to build relatively steady economic bases for firmly established life at the establishment step (the second 1.5 year of placement).

Moreover, transmigrants with other source of income outside the primary agricultural commodity from side-job as the rubber tapping labors or in maintaining the lands for rubber plants in other transmigration locations have generally felt economically sufficient to meet everyday basic needs. After cultivating the rubber plant in the Cultivation Land I that was given for 0.75 hectare in wide, while waiting the harvest of rubber plants at the next sixt year of the cultivation, they have generally been not worried about the lack of income after the living allotment of government ceased to give. They applied the living model with a relatively fixed income, but increasingly less sufficient. Amidst the increased needs for improving their life after going through the first three years of placement they have often felt to be necessary or even forced to borrow some money for meeting everyday basic needs. Their debt generally increased more and more without being able to pay in full immediately or timely because their rubber plants are still far from the period of production. In the condition, the economic conditions are not increasingly steady, but gradually indicates unobvious prospect due to the fact that the rubber harvesting period is still far at a range of four to five years.

The transmigrants with handycraft skills or smallscale trading skills have developed economically. They have not only had the types of work with cash income and can be reuse for the small-scale investment, but also they have generally been more careful in spending the money. They have been able to measure their capacity to reuse the money for consumption and investment in short-term or long-term. After cultivating the rubber plant in the Cultivation Land I given by government, they can develop the existing small-scale service busines or seek other similar activities that are potential to be other relatively steady source of income before the rubber plants are productive. The urge of buying vehicles appears, but their calculation and economic bases have more been better than those with only sidejob as the rubber tapping labors or in the maintaine of lands for rubber plants with a sharing profit system. In view of economic perspective, they are more prosperous than those with less productive activity outside the primary commodity cultivated and with only side-job as the rubber tapping labors or in the maintenance of lands for rubber plants with the sharing-profit system.

The effect of other relatively established source of income have begun to appear at the third year of placement. Those with no other source of income tended to have no expectation to continue their life in the transmigration location. On the one hand, the waiting peri- od of time for rubber plant production is still at a range of four and five years, while on the other hand, the life is going on with no adequate livelihood strategy and other source of income. They generally have survived by loans, but have no sufficient capacity to pay in full except by selling the lands for house and yard as well as the Cultivation Land I planted by the rubber plants minimally. Most of them are those from local population and chosen to leave the transmigration location, while a part of them are those from DKI Jakarta, and others are those from Pasuruan, East Java, to go back to the region of origin. Without selling the lands for house and yard as well as the Cultivation Land I, they did not have livelihood strategy and other source of income to survive in waiting for the rubber plant harvesting time of four to five years. The movement of transmigrants in going back to the region of origin has generally occured at the beginning of the third year of placement, particularly after the earthquake of 2007.

The life of the transmigrants relying on the sidejob as the rubber tapping labors or in the maintenance of lands for rubber plants in other transmigration locations with the sharing-profit system is better than those with no source of income. However, at the initial development step, actually there are two things that can make the transmigrants not feeling at home in a longer time in the transmigration location i.e. (a) considering that the field toward city, market or other developed regions are heavy, they tended to be tempted for buying vehicle by credit without consideration of paying capacity. The burden of credit can relatively be born when their income is normally earned, but they become vulnerable to suffer bad credit because of being trapped by loan that must be paid by installment regularly with no fixed and sufficient income; and (b) the decreased international market price of rubber, causing them greatly vulnerable to the terminations of employment as rubber tapping labors or of cooperation with the the owner in the maintenance of lands for rubber plants with sharing-profit system. The effect is an accumulatively increasing loan burden until a teens of million rupiahs because of the lace of money to meet the everyday basic needs, exaggerated by the burden of vehicle credit, which cannot be paid in full except by selling the lands for house and yard an/or the Cultivation Land I that are not steady to harvest. If one of the two conditions occured, generally they will not be safe and prosperous, and want to leave from the transmigration location due to relatively poor conditions.

The situation is rather different with that of those with either handycraft or small-scale trading skills. Since the beginning, they have understood that the skills will be very required in other developed transmigration locations, meaning that their income will fixedly flow in a sustainable manner. The reward for these service is relatively large and cash in nature, so that they can reuse it for investment in larger scale services such as to be carpenters or crafstment for other 
household equipments, rubber collector in transmigration location and supply it to the larger rubber collector in subdistrict towns, buying vehicle to serve commuters from transmigration location to market or other location in towns and vice versa, opening small stalls for everyday basic needs in the transmigration location and other location, providing secondary public facilities for the transmigrants such as electricity, being brokers in the selling-buying of lands, and so on. Those ideas have indeed appeared since the establishment step, but they have been more steady at the development step with a relatively stronger capital basis. In fact, they have been relatively succesful in establishing the environment of temporary or permanent settlement in transmigration location as natural or artificial geographic community with a better quality for safety and comfort for them as residents [Yunus, 1987]. They have successfully adapted to physical and non-physical environmental conditions

Table 1. Differences in Livelihood Strategies and their Effect on Welfare among the Transmigrants from Loc Population, DKI Jakarta, and Pasuruan, East Java, at Stage I of Adaptation, Stage II of Establishment, and Stage III of Development

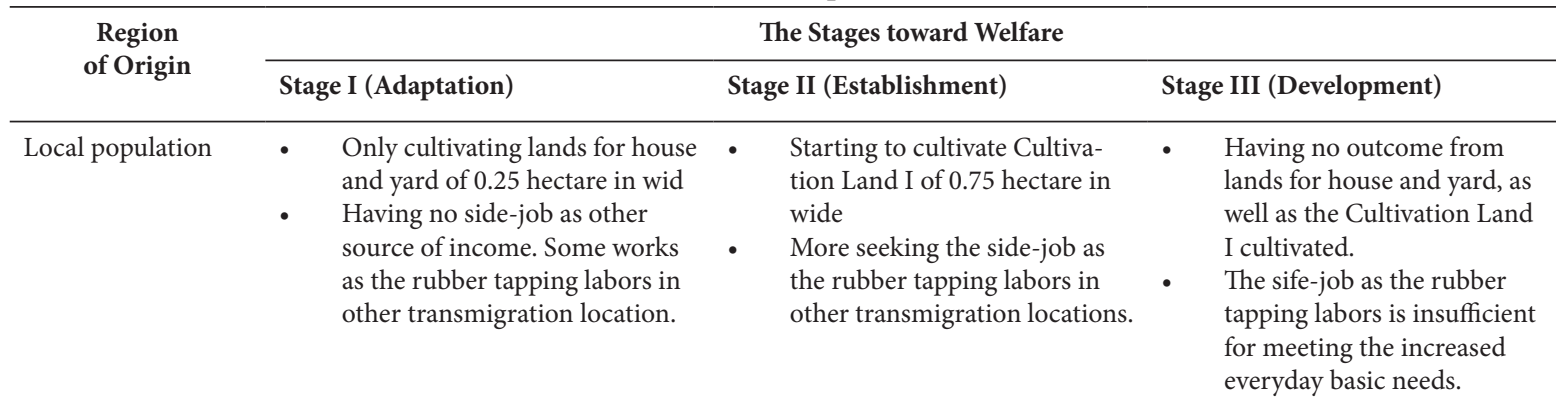

DKI Jakarta

Pasuruan, East Java
- Cultivating the lands for house and yard of 0.25 hectare in wide.

- Mostly seeking the side-job as the rubber tapping labors in other transmigration locations

- Involving in cooperation for maintaining the lands for rubber plants with sharing-profit system, particularly toward a harversting period of rubber plants.

- $\quad$ Few rent fertile lands in other transmigration locations for the cultivation of rice, pepper, or vegetables.
- Starting to cultivate Cultivation Land I of 0.75 hectare in wid

- Continuing to work in the side-job as the rubber tapping labors in other transmigration locations.

- Continuing the cooperation in maintaining the lands for rubber plants with sharing profit system, particularly toward the harvesting period of rubber plants.
- Having no outcome from lands for house and yard, as well as the Cultivation Land I cultivated.

- The sife-job as the rubber tapping labors is still sufficient for meeting everyday basic needs, but they are vulnerable to bear financial burden due to increasing loans and/or secondary needs such as buying vehicle with no accurate calculation.

Starting to cultivate Cultiva-
tion Land I of 0.75 hectare in
wide.
Continuing to work in
the side-jobe as carpenter,
small-scale trader, or the
rubber tapping labors om
other locations, but started to
make more investment in the
existing service sectors, such
as adding work equipments as
well as other facilities
Continuing to rent the fertile
lands for the cultivation of
rice, pepper, and vegetables.

- Having no outcome from lands for house and yard, as well as the Cultivation Land I cultivated.

- The sife-jobs as carpenter, mason, small-scale trader, or the rubber tapping labors are increasingly sufficient for meeting the everyday basic needs, and the works are the relatively established sources of income for sustainable welfare before rubber plants are productive in the next three or four years.

- The fertile lands rented in other transmigration locations for the cultivation of rice, pepper, and vegetables increasingly become the established source of income before rubber plants are productive in the next three or four years. 
to create a conducive residency [Bintarto, 1987].

The transmigrants' welfare condition has been much better than those from local people that are less productive and from DKI Jakarta or Pasuruan, East Java, that only relied on the side-job as the rubber tapping labors or in the maintenance of lands for rubber plants in other locations with the sharing-profit system. Thus, it can be said that those from Pasuruan, East Java, have relatively been more succesful to build other relatively more established source of income because they have sought to apply livelihood diversification strategy, particularly in nonagricultural sector, i.e. small-scale service sector for population in the surrounding transmigration location. This important finding is so consistent with Brons[2005].

However, there are tendencies to leave the transmigration location. It is generally true among those that cannot apply relatively established livelihood strategies and have no other sufficient source of income. This tendency indicates the problem suffered by the transmigrants concerning the relatively low level of welfare. In view of ecological perspective, the condition is caused by the inharmonious interaction of transmigrants in transmigration location and surrounding natural and socio-cultural environments, leading them selling their lands for house and yard as well as the Cultivation Land I, and then leaving transmigration location. They are generally from the poor families, and in the location they have no initiative to manage the lands and the surrounding environments well for optimal economic livelihood. It is actually exaggerated by the less intensive efforts of local government in building the regional land management with a environment concept for sustainable livelihood in the transmigration location. It shows one of the manifestations of failure in social interaction in the transmigration location and indicate that the policy related to the implementation of transmigration in TSU Durian Amparan indirectly affected interactiove behaviors among populations. [Harahap, 2002].

The interaction of people with surrounding natural and socio-cultural environment in the transmigration program should occur in space and time [Stephan, 1972], meaning that it must be constructed to prevent both confictual and disintegrative dimensions in the transmigration location over times. The tendency to leave TSU of Durian Amparan shows that the transmigration program is less successful in building transmigrants to developing adequate livelihood strategies for a sustainable welfare. Approximately $115 \mathrm{HH}$ left transmigration location due to the fact that they have generally been not able to develop adequate and sustainable economic basis since the adaptation step, continuing at the establishment step, and also at the development step. They have been not able to make adaptation and not take into account the causal interaction of activities they done and the surrounding environment both lands for house and yard and the Cultivation Land I as well as the surrounding socio-economic potentials to develop adequate livelihood strategies. In fact, in view of ecological perspective, as one of the three geographical perspectives [Alfandi, 2001] the unknowness, reluctance or passiveness of most transmigrants over the most appropriate livelihood strategies in sustaining lives between rubber planting period and rubber harvesting time ranging from six to seven years are the underlying causes of weakness in building sustainable economic bases, causing them feeling not at home and want to leave transmigration location in a unresponsible manner.

\section{Conclusion}

The outcome of some livelihood strategies applied by the transmigrants at Stage I of Adaptation (the first 1.5 years), Stage II of Establishment (the second 1.5 years), and Stage III of Development (the third 2 years and afterward) in achieving welfare in the transmigration location differed among the transmigrants from local population, DKI Jakarta, and Pasuruan, East Java. Actually, the difference can be seen since they were placed in the transmigration location.

In view of physical aspect, transmigrants from $\mathrm{Pa}$ suruan, East Java, have relatively been more prepared in managing lands for house and yard, and the Cultivation Land I using better land management techniques in land processing and use, planting pattern and efficient technology than those from local population and DKI Jakarta. In view of socio-cultural aspects, the transmigrants from Pasuruan, East Java, have had much stronger socio-cultural bonds in facing the heavy challenges of work in transmigration location in the heavy physical environment than those from local population and DKI Jakarta. In view of economic aspect, the side-job developed by transmigrants from Pasuruan East Java generally in handycraft and small-scale trading sectors with cash earnings that are sufficient and can be used for investment in more types of productive works, giving assurance for the sustainable livelihood strategies for the transmigrants' welfare at the development step than those from local population and DKI Jakarta.

Finally, it can be concluded that livelihood strategies applied by transmigrants from Pasuruan, East Java, have generally able to build independent economic basis in terms of developing collective welfare condition in a sustainable manner particularly if seen from their capacity to related themselves to the existing economic growth centers in the regional areas of KTM Lagita, which are proof to be able to develop and become independent economically.

\section{Acknowledment}

Thanks the promotors for their guidance in writing dissertation, and a part of the results of the study is reported in this journal. 


\section{References}

Alfandi, W. (2001), Epistemology of geography (in Bahasa), Gajah Mada University Press, Yogyakarta.

Beaudry, P., \& Green, D.A. (2002), Population Growth, Technological Adoption, and Economic Outcomes in the Information Era, Review of Economics Dynamics 5 .

Bintarto \& Hadisumarno, S. (1987), Geography analysis methods (in Bahasa), LP3ES, Jakarta.

Brons, J. E. (2005), Diversification in Rural Livelihoods: The Role of Farm Supplementary Income in Burkina Faso, Dissertation, Wageningen University.

Harahap, N. (2002), Interaksi Sosial Transmigran dengan Penduduk Lokal: Studi tentang Pola dan Faktor-faktor yang Mempengaruhi Interaksi Penduduk di Kendari (in Bahasa), Dissertation, Gadjah Mada University.

Husodo, S. Y. (2003), Transmigration: requirements of an archipelago with unbalanced heterogeneous population distribution (in Bahasa), PT Tema Baru, Jakarta.

Iden, G., \& Richter, C. (1971), Factors Associated with Population Mobility in the Atlantic Coastal Plains Region, Land Economics 47:189-193.

Kinsey, B.H. (2002), Survival or Growth? Temporal Dimensions of Rural Livelihoods in Risky Environments, Southern African Studies 28.

Lee, E.S. (1991), Migration theory (in Bahasa), Population Research center, University of Gadjah Mada, Yogyakarta.

Lincoln, Yvona S., \& Egon G.G. (1985), Naturalistic Inquiry, Sage Publications, Beverly Hills.

Miles, M.B., \& Huberman, A.M. (2009), Qualitative data analysis (in Bahasa), UI-Press, Jakarta.
Moleong, L.J. (2009), Qualitative research methodology (in Bahasa), Rosdakarya, Bandung.

O'Connor, C.M. (2004), Effect of Central Decisions on Local Livelihoods in Indonesia: Potential Synergies between the Programs of Transmigration and Industrial Forest Conversion, Population and Environment 25 .

Ramadhan K.H., et al. (1993), Transmigration: expectancy and challenges (in Bahasa), P.D. Karya Jaya Bhakti, Jakarta.

Rijanta, R. (2003), Migrasi dan Pembangunan Regional antara Mitos dan Realitas: Perspektif Teori, Kondisi Empirik Indonesia, dan Prospeknya dalam Era Otonomi Daerah (in Bahasa), Majalah Geografi Indonesia 17 (1): 1-20.

Soegiharto, S. (2008), Transmigration: learning from success stories (in Bahasa), Pustaka Sinar Harapan, Jakarta.

Stephan, G. E. (1972), Interacting Populations in Space and Time: A Paradigm for the Quantitative Analysis of Social Structure', The Pacific Sociological Review15(3): 309-326.

Suparno, E. (2008), Transmigration in new paradigm: towards people's prosperity (in Bahasa), Department of Labour and Transmigration, Republic of Indonesia, Jakarta.

Yin, R.K. (2011), Case study: design and methods (in Bahasa), Raja Grafindo Persada, Jakarta.

Yunus, H.S. (1987), Geografi Permukiman Perkotaan dan Beberapa Permasalahan Permukiman di Indonesia (in Bahasa), Master program dictate. Geography Faculty Gadjah Mada University, Yogyakarta. 